\title{
連続箱析における中間支承部の応力状態について \\ ON THE STRESS DISTRIBUTION NEAR INTERMEDIATE SUPPORT IN CONTINUOUS BOX GIRDERS
}

\author{
清 水 茂*・梶田建 夫**.成 岡 昌 夫*** \\ By Shigeru SHIMIZU, Tateo KAJITA and Masao NARUOKA
}

\section{1.はじめに}

近年，橋梁の主桁に箱断面桁が用いられることが多く なったが，1969 年から 1971 年にかけて，箱桁の架設中 の事故があいついだ.そのなかでも特に, 英国の Milford Haven 橋の事故は, 中間支承上のダイヤフラムの 耐荷力が不足していたのが原因とされている ${ }^{1)}$ 。この事 故以後, ダイヤフラムに関する研究がいろいろ行われた が，それ以前のものも含め，ダイヤフラムを含んだ箱桁 に関する研究には，次のようなものがある.

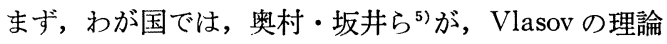
を抁張 し, Cheung ${ }^{22}$ が導いた FSM (有限帯板法, Finite Strip Method) と同様な手法を提案し, それを, 中間ダイヤフラムを有する箱桁に応用している 文献 20)においては，中間ダイヤフラムはシャイベとし て扱っている. また，文献 2) 4) は，ダイヤフラムは 面内に完全に剛としたもので, 集中ずり荷重の場合の実 験と比較し, この仮定が妥当であるとしている ${ }^{2)}$. 坂井 らは,さらに, 一般化座標から, 一種のブロック要素を 用いた方法 ${ }^{23)}$ を提案している. また，中村は，文献 5) の方法を中間ダイヤフラムを有する箱桁の動的解析に応 用した ${ }^{19)}$. 平嶋ら ${ }^{27)}$ は, Vlasov の理論を用い, 中間ダ イヤフラムの効果を調べている.

さらに，吉村ら ${ }^{61,25), 28)}$ は，箱桁とダイヤフラムの間 の不静定力を求める方法により, FSM を中間ダイヤフ ラムを有する箱桁の解析に㧒張した.

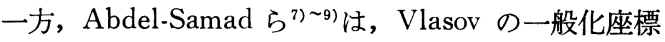
から, 弾性地盤上のはりとダイヤフラムを有する箱桁の 類似性に着目し，いわゆる BEF (Beam on Elastic Foundation) アナロジーを提案した. これは, その後,

* 学生会員 工修 名古屋大学工学部土木工学科博士課程

** 正会員 工博 名古屋大学助教授 工学部土木工学科

*** 正会員 工博 名古屋大学教授 工学部土木工学科
Milford Haven 橋事故調査委員会 (Merrison 委員会) の設計基準 ${ }^{1}$ に採用された。 また，坂井ら ${ }^{24)}$ は， $\mathrm{BEF}$ アナロジーを修正したものとして，Beam アナロジーを 提案している.

Djubek $5^{10)}$ \&，Vlasov の一般化座標を用いて，一 室から四室までの箱析を解き，Abdel-Samad とよく一 致する結果を得ている.

しかし, Chapman ら ${ }^{11)}$ にると, BEF アナロジーで は，曲げやねじり，そりに伴うせん断ひずみは考虑でき ない，としている。 また，文献 11）は，BEF のほか, FEM (有限要素法, Finite Element Method) を用い, いくつかのモデルを設定して比較している. CampbellAllen らは，BEF アナロジーをコンクリート箱析に適 用したが，コンクリート箱桁では，支承部をのぞいて は，ダイヤフラムはあまり効果がない，としている ${ }^{12)}$. Sisodia, Cheung ら $^{13)}$ は, FEM を用いて斜の箱桁を扱 い, 同様に, コンクリート箱桁では, 中間ダイヤフラム は効果がないばかりでなく，むしろ有害でさえあるとし た.

Rabizadeh $^{14)}$ らは, ダイヤフラムに長方形要素, 棒要 素を用い, FEM によって解析した。 一方, Lee ${ }^{15)} ら は ，$ FEM の自由度を減らすために, ダイヤフラムは入れ ず，その位置で箱桁の隅角部を直角に保つように拘束を 加えることにより，ダイヤフラムの代用とした.

また, Priestley, M.J.N. ${ }^{26)}$ は, 合成樹脂による模型 実験を行い，FSM，三次元および二次元の FEM，BEF などの解と比較している.

ダイヤフラムの面内応力を扱ったものとしては, ElGaaly らの研究がある ${ }^{16), 17)}$.これは, ダイヤフラムだけ を取り出し, シャイベとして FEM で解いたもので, ダイヤフラムの座屈までを扱っている. また, Puthli ${ }^{29)}$ らは，ダイヤフラムにごく短いフランジなどがついた。 いわば周辺を補強されたシャイベとしたものを FEM で解き, ダイヤフラムの強度を求めている. Dowling 
$ら^{18)}$ は，実験によりダイヤフラムの応力分布や座屈形状 を調べた.これは，Merrison 委員会の研究の一部とし て行われたものである.

著者らも, 文献 19）と同様な方法で中間ダイヤフラム を有する箱桁を解析し，ダイヤフラムの変形を考虑した 場合を，剛性を無限大とした場合と比較している211.

以上のよらに，箱桁に関する研究は多いが，そのほと んどは, 断面変形などの箱桁の挙動に注目したもので女 りまた，その多くは1スパンのみを扱っている.ダイ ヤフラムの面内応力に 注目した研究は, 文献 16) 18) などにみられるが，文献 18）は単純桁についての実験的 な研究であり, 文献 16),17）,29）は支承上のダイヤフ ラムを解いているものの, ダイヤフラムのみをシャイベ のように扱っている.ダイヤフラムの必要剛度などにつ いては, Merrison レポードに詳しく述べられている が,これは式が繁雑であるなどの久点を持っている ${ }^{24)}$. 坂井らは, 文献 24) において, 中間ダイヤフラムの応 力をはじめ, 必要剛度, ダイヤフラムの間隔などについ て, 設計式を提案している.

本論文においては，従来あまり顧みられなかった，連 続箱析の中間支承部に着目し，中間支承上のダイヤフラ ムの面内応力や中間支承近傍での箱桁の応力を調べた.

これには, 文献 6) や25) などに述べられている中間ダ イヤフラムと箱析の間の不静定力を求める方法を応用し た. また，得られた中間支承上のダイヤフラムの面内応 力分布は, 文献 16) に示された結果と比較している.

また，ダイヤフラムにリブがついた場合も扱い，リブ の効果を調べた.

\section{2. 解析法の概要}

ここでは, 中間ダイヤフラム・中間支承上のダイヤフ ラムを有する連続箱析を解析する手順について述べる.

解析は, 箱桁については FSM を, ダイヤフラムには FEM を用い，箱桁とダイヤフラム・中間支承の間の 不静定力を求めたのち, それを荷重として箱桁に作用さ せることによって行われている．これは，基本的には文 献 25) などと同じものである.

a) 仮 定

解析にあたって, 次の仮定を置く.

（i ）桁の両端は単純支持されており，また，両端に は, 面内剛性無限大, 面外には抵抗しないダイヤフラム があるものとする.

(ii) 中間ダイヤフラム（中間支承上のダイヤフラム も含む） は平面応力状態にあるものとし，その曲げ剛性 は無視する. 対傾構やリブのような棒要素を考えるとき も, その曲汿剛性は考えない。 (i) の仮定は FSM そのものの仮定である. (ii) の仮 定は Merrison レポート1で妥当であるとされている.

\section{b）不静定力の誘導}

まず，中間支承・中間ダイヤフラムをすべて取り去っ た系に, 与えられた荷重を作用させた場合の, 不静定力 を作用させる場所での箱析の変位を，FSM により計算 する（この系を基本系とする）。この変位を $\left\{\delta_{0}\right\}$ とす る. ただし， $\left\{\hat{o}_{0}\right\}=\left\{\left\{\delta_{01}\right\}^{T}\left\{\hat{o}_{02}\right\}^{T} \cdots\left\{\delta_{0 i}\right\}^{T} \cdots\right\}^{T}:\left\{\hat{o}_{0 i}\right\}=$ $\left\{u_{1 i}{ }^{0}, w_{1 i}{ }^{0}, u_{2 i}{ }^{0}, w_{2 i}{ }^{0}, \cdots, u_{n i}{ }^{0}, w_{n i}{ }^{0}, \cdots\right\}^{T}$ であって, $u_{n i}{ }^{0}, w_{n i}{ }^{0}$ は， $i$ 番目の中間ダイヤフラム（または中間 支承）に抢ける $n$ 番目の節線の， $x$ 方向， $z$ 方向の変 位である（座標の取り方は，Cheung の論文 ${ }^{22)}$ と同じで ある)。

一方，たわみ性マトリックスを $[F]$ として，

$$
\left\{\delta_{1}\right\}=[F] \cdot\left\{X_{1}\right\} \cdots \cdots \cdots \cdots \cdots \cdots \cdots \cdots \cdots \cdots(1)
$$

ただし, $\left\{\delta_{1}\right\}=\left\{\left\{\delta_{11}\right\}^{T},\left\{\delta_{12}\right\}^{T}, \cdots,\left\{\delta_{1 i}\right\}^{T}, \cdots\right\}^{T}:$ $\left\{\delta_{1 i}\right\}=\left\{u_{1 i}{ }^{1}, w_{1 i}{ }^{1}, u_{2 i}{ }^{1}, w_{2 i}{ }^{1}, \cdots, u_{n i}{ }^{1}, w_{n i}{ }^{1}, \cdots\right\}^{T} ;\left\{X_{1}\right\}$ $=\left\{\left\{X_{11}\right\}^{T},\left\{X_{12}\right\}^{T}, \cdots,\left\{X_{1 i}\right\}^{T}, \cdots\right\}^{T} ;\left\{X_{1 i}\right\}=\left\{X_{1 i}{ }^{1}, Z_{1 i}{ }^{1}\right.$, $\left.X_{2 i}{ }^{1}, Z_{2 i}{ }^{1}, \cdots, X_{n i}{ }^{1}, Z_{n i}{ }^{1}, \cdots\right\}^{T}$ であって, $X_{n i}{ }^{1}, Z_{n i}{ }^{1}$ は, $i$ 番目の中間ダイヤフラム（または中間支承）に扔ける 第 $n$ 節線の, $x$ 方向, $z$ 方向の不静定力である.

また, 中間ダイヤフラムがある場合, その剛性マトリ ックスを $[K]$ として,

$$
\left\{X_{2}\right\}=[K] \cdot\left\{\delta_{2}\right\} \text {. }
$$

c）中間ダイヤフラムの場合

適合条件加，

$$
\begin{aligned}
& \left\{\delta_{0}\right\}+\left\{\delta_{1}\right\}=\left\{\delta_{2}\right\} \\
& \left\{X_{1}\right\}+\left\{X_{2}\right\}=0
\end{aligned}
$$

式 (3)，(4) と (1), (2) を用いると, 不静定力 $\left\{X_{1}\right\}$ は,

$$
\left\{X_{1}\right\}=-([I]+[K][F])^{-1}[K]\left\{\delta_{0}\right\} \cdots \cdots(5)
$$

となる. この場合は, 文献 6$)$ などとまったく同じであ る. $[I]$ は単位行列である.

\section{d）中間支承がある場合}

中間支承上での $\left\{\delta_{0}\right\},\left\{\delta_{1}\right\},\left\{X_{1}\right\}$ などを，直接支持さ れている節線（節点）に関する部分と, そうでない部分 とに分けて考える.すなわち，

$$
\left\{\delta_{0}\right\}=\left\{\begin{array}{c}
\bar{\delta}_{0} \\
\overline{\bar{\delta}_{0}}
\end{array}\right\},\left\{\delta_{1}\right\}=\left\{\begin{array}{c}
\bar{\delta}_{1} \\
\overline{\bar{\delta}_{1}}
\end{array}\right\}, \quad\left\{X_{1}\right\}=\left\{\begin{array}{c}
\bar{X}_{1} \\
\bar{X}_{1}
\end{array}\right\}
$$

などである. ここで, 上線一本の部分は, 支承と接して いないもので，上線二本の部分が，支承と接しており， 直接支持されている節線（節点）に関するものである. すると，(1),(3) は抢のおの

$$
\begin{aligned}
& \left\{\begin{array}{c}
\bar{\delta}_{1} \\
\overline{\overline{\delta_{1}}}
\end{array}\right\}=[F]\left\{\begin{array}{c}
\bar{X}_{1} \\
\overline{X_{1}}
\end{array}\right\}=\left[\begin{array}{ll}
F_{11} & F_{12} \\
F_{21} & F_{22}
\end{array}\right]\left\{\begin{array}{c}
\bar{X}_{1} \\
\bar{X}_{1}
\end{array}\right\} \cdots(6 \cdot \mathrm{a}) \\
& \left\{\begin{array}{c}
\bar{\delta}_{0} \\
\overline{\bar{\delta}_{0}}
\end{array}\right\}+\left\{\begin{array}{c}
\bar{\delta}_{1} \\
\overline{\bar{\delta}_{1}}
\end{array}\right\}=\left\{\begin{array}{c}
\bar{\delta}_{2} \\
0
\end{array}\right\} \cdots \cdots \cdots \cdots \cdots \cdots \cdots \cdots(6 \cdot \mathrm{b})
\end{aligned}
$$

となり，また，(2) も次のようになる. 


$$
\left\{\begin{array}{c}
\bar{X}_{2} \\
\bar{X}_{2}
\end{array}\right\}=\left[\begin{array}{ll}
K_{11} & K_{12} \\
K_{21} & K_{22}
\end{array}\right]\left\{\begin{array}{c}
\bar{\delta}_{2} \\
0
\end{array}\right\}=\left[\begin{array}{c}
K_{11} \\
K_{21}
\end{array}\right]\left\{\bar{\delta}_{2}\right\} \cdots(7)
$$

式 $(6 \cdot \mathrm{a})$ より $\left\{\bar{\delta}_{1}\right\}=\left[\begin{array}{ll}F_{11} & F_{12}\end{array}\right]\left\{X_{1}\right\}$ であり, 式 $(6 \cdot \mathrm{b})$ より $\left\{\bar{\delta}_{0}\right\}+\left\{\bar{\delta}_{1}\right\}=\left\{\bar{\delta}_{2}\right\}$ であるから， c) の場合と同様に $\left\{\bar{\delta}_{2}\right\}$ を消去すると,

$$
\left\{X_{1}\right\}=-\left([I]+\left[\begin{array}{l}
K_{11} \\
K_{21}
\end{array}\right]\left[\begin{array}{ll}
F_{11} & F_{12}
\end{array}\right]\right)^{-1}\left[\begin{array}{l}
K_{11} \\
K_{12}
\end{array}\right]\left\{\bar{\delta}_{0}\right\}
$$

を得る.

中間支承上にダイヤフラムがない場合は, 式 (6・a) に おいて $\left\{\bar{X}_{1}\right\}=0$ であるから，次のようになる．

$$
\left\{\begin{array}{c}
\bar{\delta}_{1} \\
\overline{\bar{\delta}}_{1}
\end{array}\right\}=\left[\begin{array}{ll}
F_{11} & F_{12} \\
F_{21} & F_{22}
\end{array}\right]\left\{\begin{array}{c}
0 \\
\overline{\bar{X}}_{1}
\end{array}\right\}=\left[\begin{array}{l}
F_{12} \\
F_{22}
\end{array}\right]\left\{\begin{array}{l}
\bar{X}_{1} \\
\}
\end{array} \cdots \cdots(9)\right.
$$

式 (9) より $\left\{\overline{\bar{o}}_{1}\right\}=\left[F_{22}\right]\left\{\bar{X}_{1}\right\}$ であり, 式 $(6 \cdot \mathrm{b})$ より $\left\{\overline{\bar{\delta}}_{0}\right\}+\left\{\overline{\bar{\delta}}_{1}\right\}=0$ であるから, 不静定力 $\left\{\bar{X}_{1}\right\}$ は,

$$
\left\{\bar{X}_{1}\right\}=-\left[F_{22}\right]^{-1}\left\{\overline{\bar{\delta}}_{0}\right\}
$$

となる.

これらの式のうち, $[I]$ は単位マトリックス, $\left[K_{11}\right.$ $\left.K_{21}\right]^{T}$ はダイヤフラムの剛性マトリックスのうち, 支持 されていない節点に 関する列のみを取り出したもの， $\left[F_{11}, F_{12}\right]$ はたわみ性マトリックスのうち, 支持されて いない節線に関する行のみを取り出したものであり，
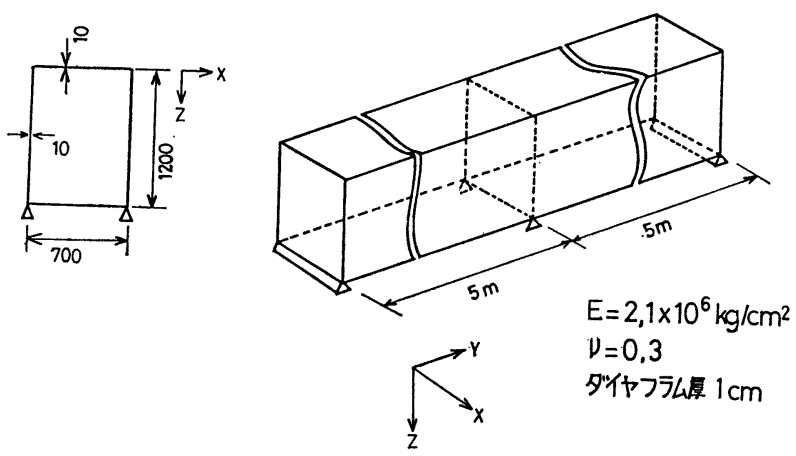

(a) 長方形断面 (夕イプR)
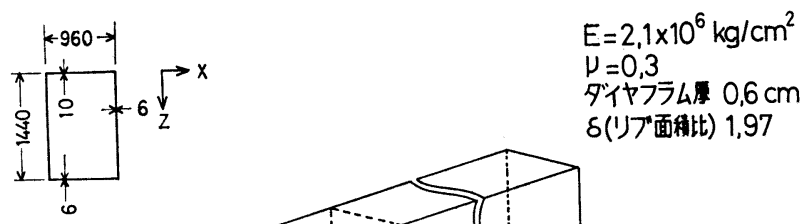

ダイヤフラム㙞 $0,6 \mathrm{~cm}$

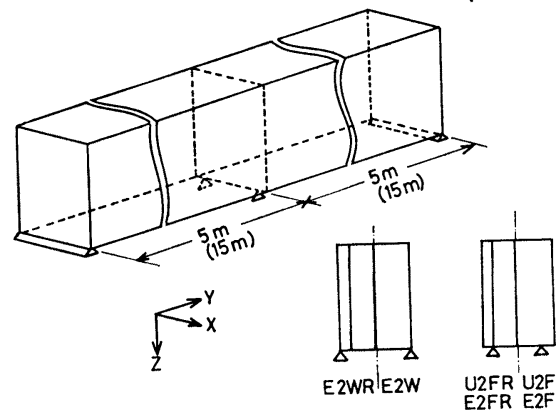

(c) 長方形断面 (タイプE)
$\left[F_{22}\right]$ はたわみ性マトリックスのうち，支持された節線 関するマトリックスである.

\section{3. 解析モデル}

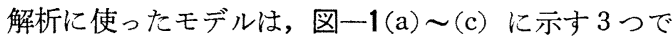
ある. 図一1(b) の断面形状は, 文献 16) に合わせてあ る.また, 図一1(c) のモデルは, 図一2 のよ5に, 連 続桁をおのおの $10 \mathrm{~m}$ の長さをもつ別々の桁として取り 出したもののうち, 中間支承部の桁である. 本論文にお いては，図一1(c) に示した長さ $10 \mathrm{~m}$ (スパン $5 \mathrm{~m} \times 2$ ) のモデルのほか, 桁全体を想定し, 長さ $30 \mathrm{~m}$ (スパン $15 \mathrm{~m} \times 2)$ のものも扱った．また，図一1(c) に示すよう に, このモデルでは, ダイヤフラムにリブがついた場合 も扱っている.

これらのモデルにおいて，中間支承は，桁中央部のウ ェブの直下にあるが，図一1(c) のモデルにおいては， 図に示したよらに, ウェブ直下ばかりでなく, $140 \mathrm{~mm}$

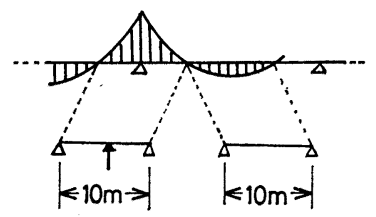

図一2 タイプ $\mathbf{E}$ 箱桁のモデル
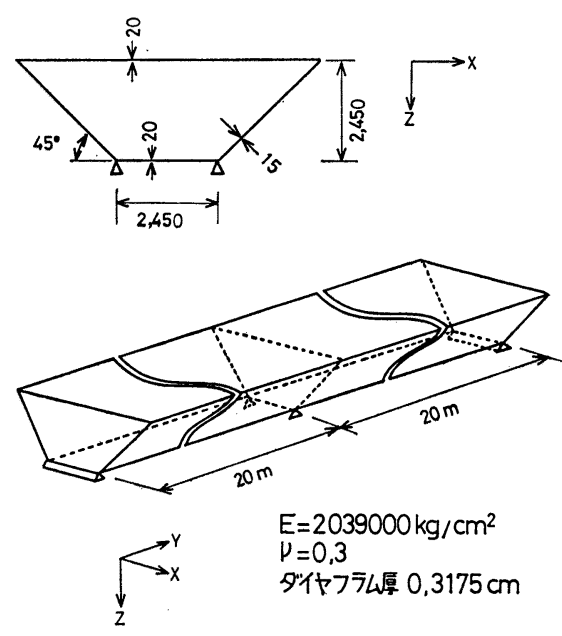

(b) 台形断面 


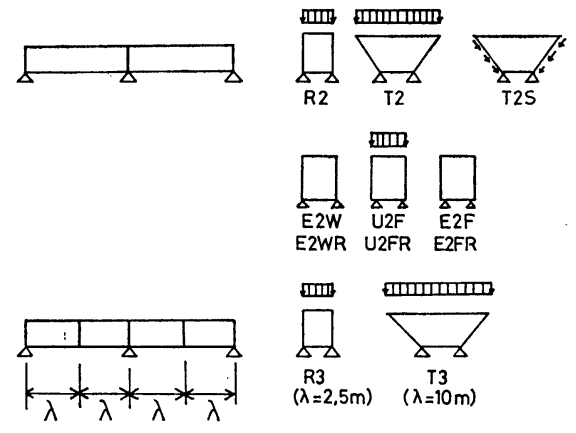

(a) タイヤフラム位置
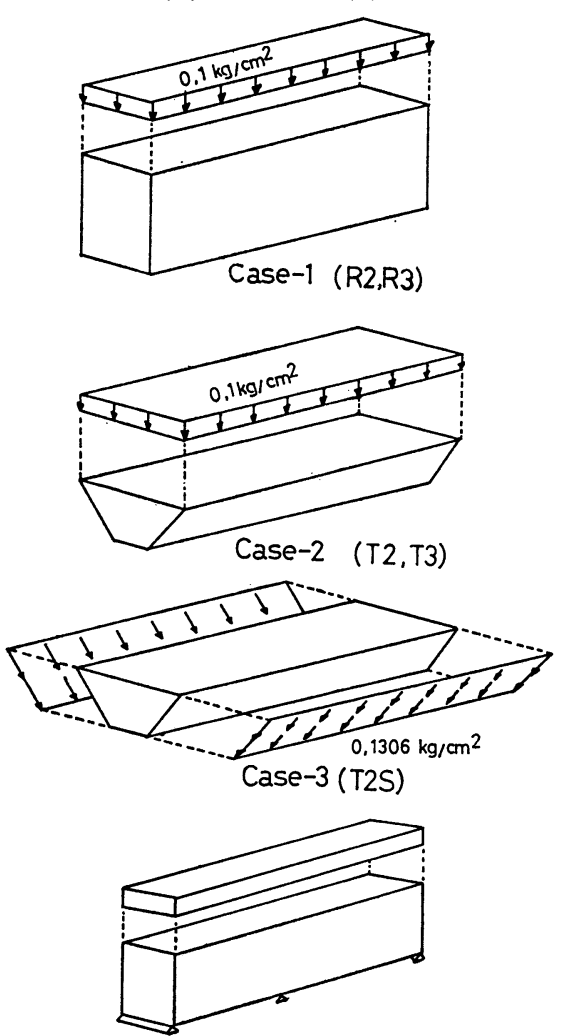

Case-4 (U2F,U2FR)
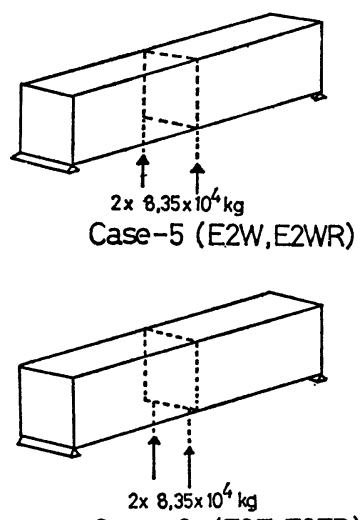

Case-6 (E2F,E2FR)

（b）载荷状態

図-3
内側に寄った場合も考えている．また，ダイヤフラムの 数や位置は 図一-3(a) に, 荷重の詳細は 図一-3(b) に示 してある. 荷重は主として上フランジに等分布荷重が満 載した場合を扱ったが, 図一1(b) の台形断面モデルで は, ウェブに対するせん断力を, 図一1(c) のモデルで は, 反力に相当する集中荷重のみを作用させた場合も考 えている（後者は, 実質的には, 単純桁に集中荷重が作 用する場合と同じである). ダイヤフラムなどの要素分 割, リブの位置や断面積については, 図一4に示してあ る.また，図一4の中にあるリブの面積比 $\delta$ は，この 場合, リブの総断面積をダイヤフラムの断面積で割って 無次元化したものであり, このモデルでは $\delta=\delta_{s}=1.97$ となっている.

これらのモデルには, 表一1 のよらに符号をつけてお

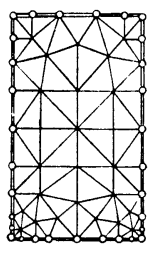

(a) 長方形断面 (タイプR)

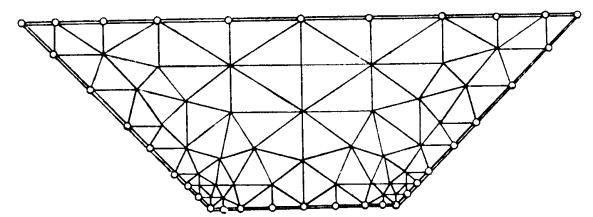

(b) 台形 断 面

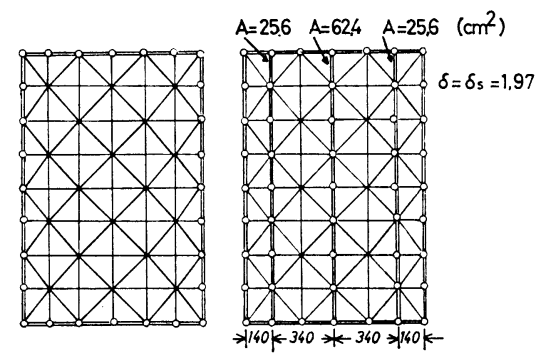

(c) 長方形断面 (タイプE,リフなし)

(d) 長方形断面 (タイプE,リプつ)

図一4 要秉分 割

表一1 モデルの符号

\begin{tabular}{|c|c|c|c|c|c|c|}
\hline & \multirow{2}{*}{\begin{tabular}{|l} 
長方形 \\
面 \\
$\left(\begin{array}{c}\text { 夕 } \\
\mathrm{R}\end{array}\right)$
\end{tabular}} & \multirow{2}{*}{ 台形断面 } & \multicolumn{2}{|c|}{$\begin{array}{c}\text { 長方形断面 } \\
(\text { タイ }\end{array}$} \\
\hline & & & & & リプなし & リプつき \\
\hline \multirow{5}{*}{ 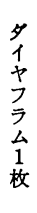 } & \multirow{2}{*}{$\begin{array}{l}\text { 等分布 } \\
\text { 荷 } \\
\text { 重 } \\
\text { 儎 }\end{array}$} & 支点はウェフ值下 & R 2 & $\mathrm{~T} 2$ & & \\
\hline & & 支点は下フランジ & & & $\mathrm{U} 2 \mathrm{~F}$ & U 2 F R \\
\hline & \multirow{2}{*}{$\begin{array}{ll}\text { 反 } \\
\text { の }\end{array}$} & 支点はウェブ直下 & & & E $2 W$ & E $2 \mathrm{WR}$ \\
\hline & & 支点は下フランジ & & & E $2 \mathrm{~F}$ & E $2 \mathrm{FR}$ \\
\hline & ウ $ェ$ & フにせん断力 & & T $2 \mathrm{~S}$ & & \\
\hline \$ & $1+$ & フ ラ $ム 3$ 枚 & R 3 & T 3 & & \\
\hline
\end{tabular}


く、また，桁の寸法やダイヤフラムの厚さ，材料定数な どは 図一1(a)〜(c) の中に示してある.

な㧍，図一3(a) に示すほか，FSM の仮定から，析 端に面内剛性無限大, 面外剛性なしのダイヤフラムがあ ることになる．以下，本論文でダイヤフラムといらの は，桁端ダイヤフラムを除いたものとする．また，以 後, 各スパンの中間にあるダイヤフラムを I.D., 中間支 承上にあるダイヤフラムを S.D. と略称する.さらに， 図一1(a) の長方形断面桁 (R 2, R 3) をタイプ R の長 方形断面桁, 図一1(c) に示した長方形断面桁 (U $2 \mathrm{~F}$, $\mathrm{U} 2 \mathrm{FR}, \mathrm{E} 2 \mathrm{~W}, \mathrm{E} 2 \mathrm{WR}, \mathrm{E} 2 \mathrm{~F}, \mathrm{E} 2 \mathrm{FR})$ をタイプ E の長方形断面桁とよぶことにする.

\section{4. 収束性の検討}

FSM では，箱桁や折板構造のように，橋軸方向に同 一の性質を持つ構造物を，橋軸と直角な断面で切断し た，いわば次元を 1 つ隇らした状態で解析する. その “断面”内での分割の考え方は, FSM も FEM も同じ である. 橋軸方向については, FEM では, 他の方向と 同様に要素分割する，いわゆる構造的近似であるのに対 し, FSM では橋軸方向の Fourier 級数を用いた数学的 近似となっている. すなわち, FSM の級数は FEM の 橋軸方向の分割に対応しているといえよう.

したがって，FSM では，級数を何項まで取るかが精 度に大きな影響を与える. そこで, 項数を変えて, 変位 や応力がどのように変わるか検討した。

図一5 は，モデル R 2 の箱桁の変位のパラメータ $w_{m}$ $\left(w_{m}\right.$ は, 鉛直方向変位 $w$ の第 $m$ 項の Fourier 係数) の収束の様子をプロットしたものである.これを見る と, 箱桁上端 (図中, 点A) の変位パラメーターは 10 項程度で収束している．集中荷重として作用する支点反 $\mathrm{kg} / \mathrm{cm}^{2}$
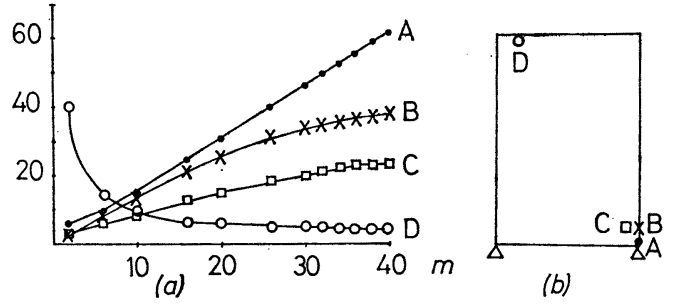

(b)

力を直接うける下端（図中, 点 $\mathrm{B}$ ) の変位パラメーター は，収束性がかなり悪いが，いずれも第 40 項目の值は 第 1 項の值の $0.8 \%$ 程度である.

中間支承上のダイヤフラム面内の 応力の 収束状況を 図一6 に示寸. 図一6 (b) に示すように, 中間支承の直上 に点 $\mathrm{A}$ ，その少し上に点 $\mathrm{B}$, 内部に入ったところに点 $\mathrm{C}$, ダイヤフラム上端に点 D を取る. 図一6(a) を見ると，

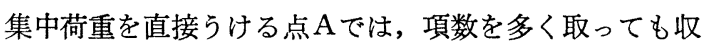
束しない. 点 $\mathrm{B}$ では, 30 項を越えたあたりから, やや 傾きがゆるやかになる傾向を見せているものの，収束性

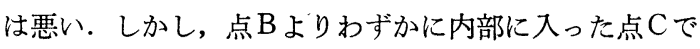
は, 38 項と 40 項の応力の差は $2.2 \%$ 程度である. 一 方, 点 D の応力值は, 20 項をすぎたあたりから, ほぼ 一定の值となっている.

以上の計算結果から，応力集中が生ずる特異点とその 近傍をのぞいては，40 項まで計算すれば，実用上十分 な精度が得られると判断される。

\section{5. 解析 結果}

a) 箱桁のウェブおよびフランジの応力

図一7 は, モデル R 2, R 3 の長方形断面のウェブの

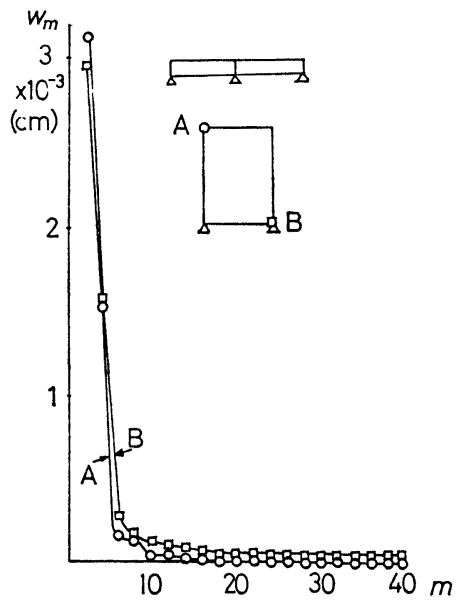

図一5 モデル R 2 における変位 $\boldsymbol{w}_{m}$ の収束性

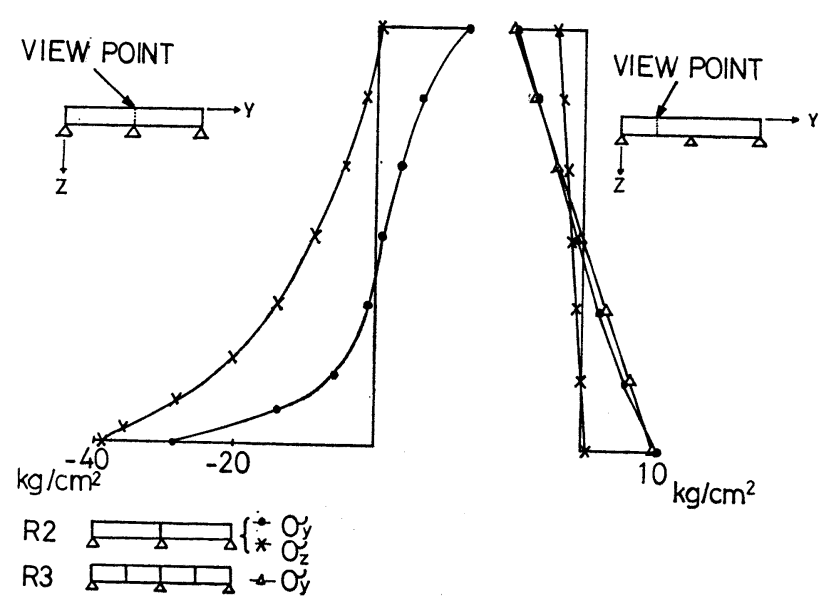

図一ワ ウェブの応力（タイプRの箱桁） 
応力分布をプロットしたものである. 橋軸方向応力 $\left(\sigma_{y}\right)$ の分布をみると, スパン中間部では，ほぼ直線分布とな っている. しかし，中間支承上では，中立軸がかなり下 に寄り，下縁で大きな応力值が現われている．鉛直方向 応力 $\left(\sigma_{z}\right)$ も, 中間支承上では, かなりの応力集中がみ られる.

図一8 は, 同じくモデル R 2, R 3 のフランジの橋軸 方向応力 $\left(\sigma_{y}\right)$ である. 中間支承上では, ウェブ直下と

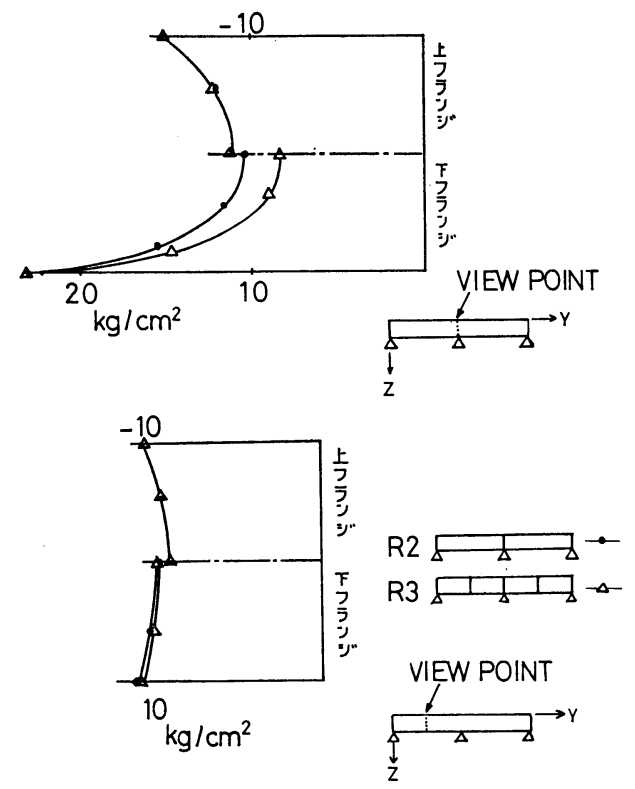

図一8 フランジの $\sigma_{y}$ の分布 (タイプ Rの箱桁)

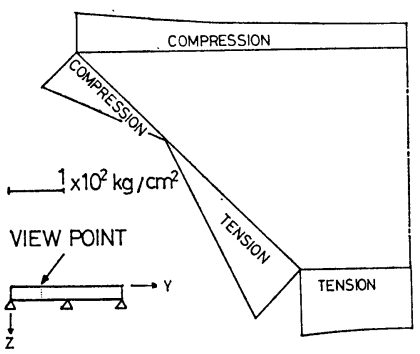

(a) スパン中央部の $\sigma_{y}$ の分布

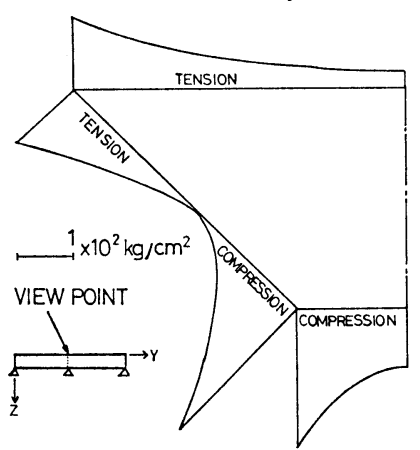

(b) 中間支承上の $\sigma_{y}$ の分布

図一9 台形断面桁のウェブ・フランジの応力
フランジ 中央部との 応力の差が 非常に 大きいのがわか る.

図一9 は, モデル T 2 の, ウェブ・フランジの橋軸 方向応力 $\sigma_{y}$ の分布である. 図一9(a) のスパン中央部に おける応力分布は, ウェブにおいてはほぼ直線分布, 上 下フランジでもフランジ端と中央部との差は, さほど大 きくない. 上フランジ端部の応力は, 中央部の 1.7 倍程 度である. 図一9(b) の中間支承部の応力分布は, タイ プRの長方形断面の場合と同じく, ウェブにおいても直 線とはならず，支承の近傍で大きな值を示している．フ ランジの応力分布においても，フランジ端部と中央部と の差が大きくなっている.

b） タイプRの長方形断面におけるダイヤフラムの応 力

図一10 は, モデル R 3 の, S.D. の応力分布である. これを見ると, 支点付近では大きな鉛直方向応力 $\sigma_{z}$ が みられる， $\sigma_{z}$ が大きな值を示寸範囲は，上方のやや内 側に向って伸びており, ダイヤフラム下縁の 中央部で は, 大きな応力值は出ていない. 一方, ダイヤフラムの 水平方向応力 $\sigma_{x}$ は, 支点近くでも大きな応力集中は生 じていない. ダイヤフラム中央のやや下寄りの部分に, 若干大きな応力が 見られる程度である. 図一10 の応力 分布, 特に $\sigma_{z}$ の分布をみると, 文献 16) にあるように, ダイヤフラム自体が, ア一チ作用により支点反力をかな り負担しているのがわかる.
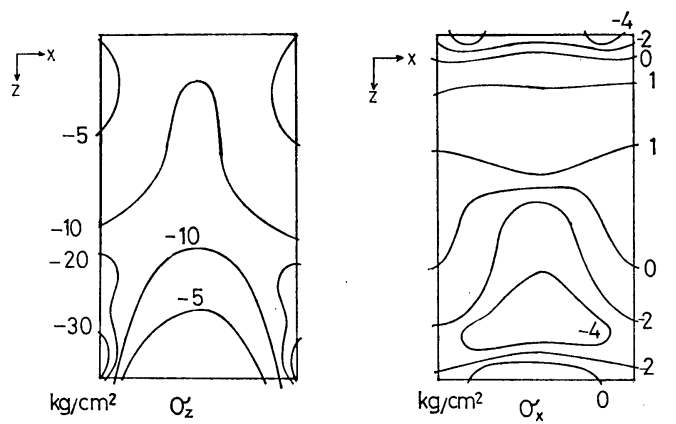

図一10 中間支承上のダイヤフラムの応力分布 (モデルR3)

一方，本論文では，ねじりを伴わない荷重を考えてい るので，このモデルでは，I.D. には大きな応力は見ら れなかった。

I.D. のないモデル R 2 の場合については, S.D.の 応力分布は R 3 とほとんど同じとなっている.

c）台形断面におけるダイヤフラムの応力分布

図一11 は, 台形断面桁のモデル T 3 における S.D. の応力分布である. 台形の場合でも, I.D. のないモデ ル T 2 の S.D. の応力分布は, T 3 の場合とほとんど 同じ分布を示している. 鉛直方向応力 $\sigma_{z}$ が支承の近傍 で特に大きな值を示し， $\sigma_{z}$ が大きな值を示す範囲がダ 


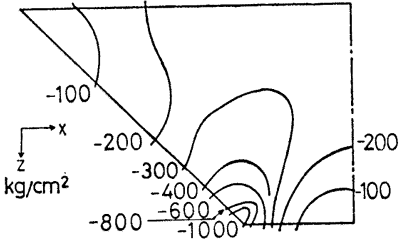

(a) $\sigma_{2}$ の分布

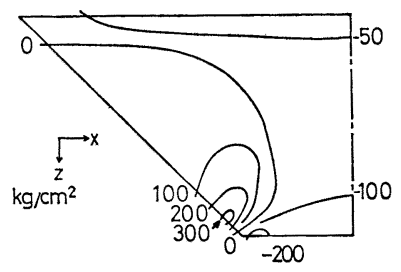

(b) $\sigma_{x}$ の分布

図一11 中間支承上のダイヤフラムの応力分布 (モデルT3)

イヤフラム中央に向って斜め上方に拡がっているのは， 長方形断面の場合と同様である. 水平方向応力 $\sigma_{x}$ は, ウェブと接している側辺沿いに引張応力が拡がり, 支承 付近では， $\sigma_{z}$ ほどでないにせよ, 大きな応力值を示し ていることが, 長方形断面の場合と異なっている.

また，台形断面では，I.D. であっても鈍角部に応力 集中がみられ， $\sigma_{z}$ の分布の傾向は, I.D., S.D. とも同 様となった.

d）リブつきダイヤフラムの応力分布

図一12(a), (b) は，等分布荷重を満載したモデルU2 F, および反力のみを考えたモデル E $2 \mathrm{~F}$ の, S.D. の鉛 直方向応力 $\sigma_{z}$ の分布図である. これを見ると, 両者と も， $\sigma_{z}$ の分布はほぼ同じとなっている. 一方, 図一13 (a), (b) は, 図一12 と同様なモデルにおいて, ダイヤ フラムにリブがついた， モデル U 2 FR, E 2 FR の S. D. の $\sigma_{z}$ の分布図である. この場合も，この 2 つの応 力分布はほぼ同じである. ここで示した図は，3. で述 ベた，桁長 $10 \mathrm{~m}(2 @ 5 \mathrm{~m})$ のモデルについての結果で

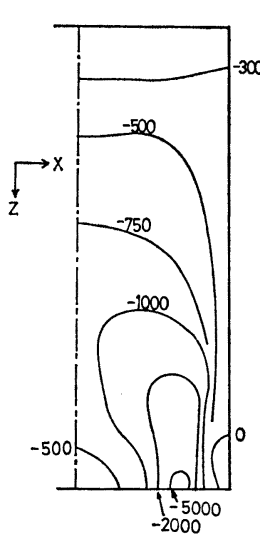

(a) U2F

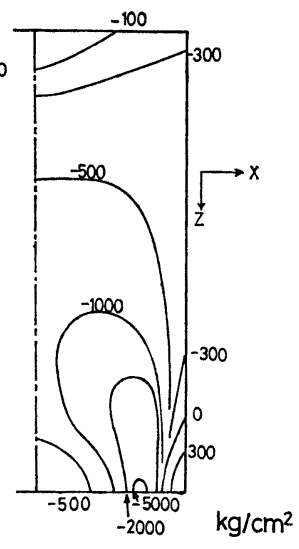

(b) $E 2 F$
図一12 タイプ $\mathbf{E}$ のダイャフラムの $\sigma_{z}$ の分布(リブなし)

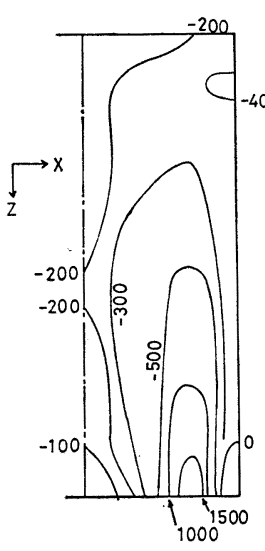

(a) U2FR

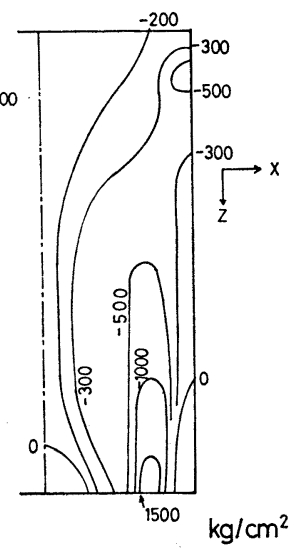

(b) E2FR
図一13 タイプ $\mathbf{E}$ のダイヤフラムの $\sigma_{z}$ の分布(リブつき)

あるが，桁の全体を想定した桁長 $30 \mathrm{~m}(2 @ 15 \mathrm{~m})$ の場 合も, S.D. における応力分布は, 図一12,13 とほぼ同 じになっている. したがって, このモデルでは, 中間支 承付近の桁中央部のみを取り出し, 単純栴化した栴に, 反力のみを集中荷重として作用させても， S.D. の応力 は評価できるといえる。

次に, S.D. にリブのない図-12(b) のモデル E 2 F と, リブがついている 図-13(b) のモデル E 2 FR を比 較してみる. E $2 \mathrm{~F}$ では, $\sigma_{\boldsymbol{z}}$ の分布の傾向は, タイプ $\mathrm{R}$ の長方形断面桁や台形断面桁と同じく，応力の大きな 領域が，支承部からダイヤフラム中央部に向け斜め上方 に拡がっている. 一方, リブつきのモデル E 2 FR では， 当然のことながら， $\sigma_{z}$ はリブのない場合に比べ 全体的 に小さくなっており，また，比較的大きな応力の見られ る範囲は，支点上のリブに沿って上方に伸びている.

次に, タイプEのモデルにつき, リブの剛度(断面積) をパラメーターとし, リブの面積比 $\delta$ を, 図一4 で示し た $\delta_{s}$ の $1 / 8,1 / 4,1 / 2,2$ 倍, 3 倍, 4 倍とした場合の， ダイヤフラムの応力 $\sigma_{z}$ の相違を調べてみる.

リブなしの場合 $(\delta=0)$ から， $\delta=1 / 2 \cdot \delta_{s}$ としたもの までは， $\sigma_{z}$ の分布の傾向は，いずれもほぼ同様となり， 応力の大きな領域が，支点からダイヤフラムの中央部に 向けて斜め上方に拡がっている. 一方, 面積比 $\delta$ を $\delta_{s}$ の $2 \sim 4$ 倍とした場合の $\sigma_{z}$ の分布傾向は, $\delta=\delta_{s}$ の場 合とほぼ同様となった. ダイヤフラム全体を通じ, $\delta$ が 大きくなるに従って $\sigma_{z}$ の值が減少するのは当然のこと と考えられるが, ダイヤフラムの特定の点に注目して, リブの面積比 $\delta$ に応じた $\sigma_{z}$ の変化を描くと, 図一14 のようになる.これは, 図-14(b) に示した (1) (3)の 各点における $\sigma_{z}$ の值であり, そのうち (1) は, その点 におけるリブの応力である.これを見ると， $\delta$ が増すに 従い $\sigma_{z}$ の減少は次第にゆるやかとなり, 注目点にもよ 
るが, リブの面積比 $\delta$ が $\delta_{s}$ の 3 4 倍程度で水平に近 くなっている.

e）支点の位置によるダイヤフラムの応力の影響 タイプEの箱析において, 中間支点がウェブの直下に あるモデル E $2 \mathrm{~W}, \mathrm{E} 2 \mathrm{WR}$ (図一15(a)，(b)）と，支点 がやや内側にある E 2 F,E 2 FR について比較してみる.

ダイヤフラムにリブがついていない場合は, 支点が内 側に寄っている E $2 \mathrm{~F}$ では，ダイヤフラムに 極端な応

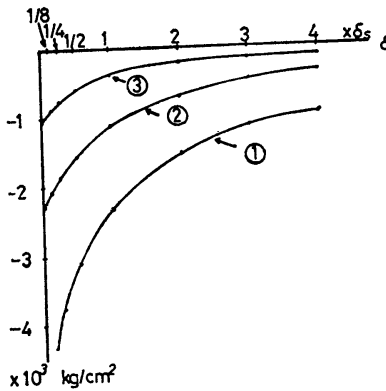

(a)

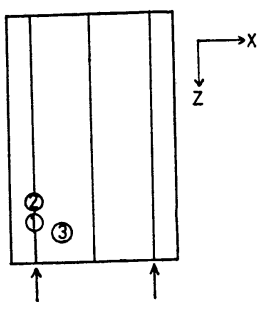

(b)
図一14 リブ剛度によるダイヤフラム応力 $\sigma_{z}$ の変化

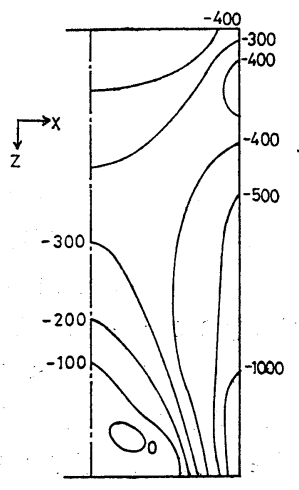

(a) $\mathrm{E} 2 \mathrm{~W}$

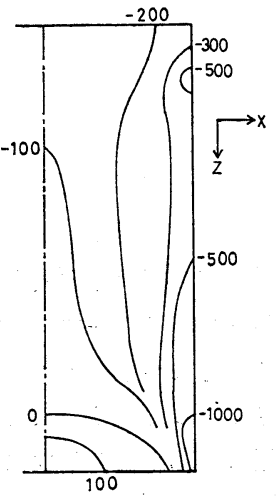

(b) $\mathrm{E} 2 \mathrm{WR}$
図一15 支点がウェブ直下にある場合のダイヤフラムの 応力 $\sigma_{z}$ の分布

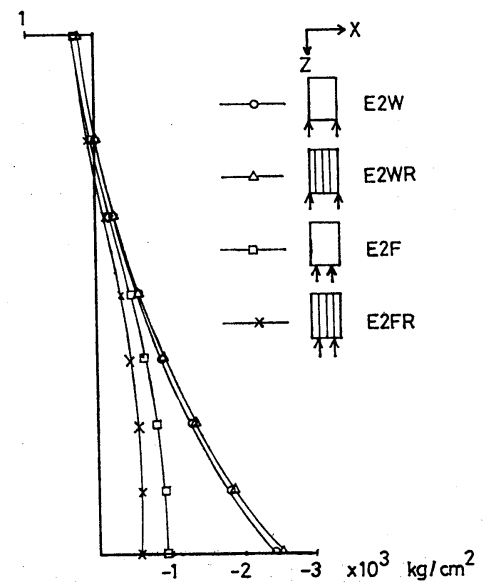

図一16 ウェブの応力 $\sigma_{z}$ の分布
力集中がみられるのに対し，支点がウェブ直下にある $\mathrm{E} 2 \mathrm{~W}$ で注，応力集中はさほど大きくなく，また，ダ イヤフラム全体にわたって小さな応力を示している、リ ブがある場合には，この差は明膫でないが，同様な傾向 がみられる.これは $\mathrm{E} 2 \mathrm{~W}, \mathrm{E} 2 \mathrm{WR}$ では, 反力がウェ ブにより支えられることによる当然の結果といえる. 実 際，この断面におけるウェブの鉛直方向応力 $\sigma_{z}$ を見る と(図一16), E 2 W, E 2 WR では大きな圧縮力が生じ ている.ダイヤフラムのリブの有無は,この $\sigma_{z}$ にはほ とんど影響しない。一方 E 2 F,E 2 FR では, ウェブの $\sigma_{z}$ はかなり小さいらえに, リブの有無による差がはっ きり認められる.

f）ダイヤフラムに作用する不静定力

本解析においては，2.で述べたとおり，箱桁とダイ ヤフラムの間の不静定力を求め, それを荷重として箱桁 やダイヤフラムにかけて解析している.すなわち, ダイ ヤフラムは, 不静定力に等しい荷重をうけるシャイベと 考えることもできる. このダイヤフラムに作用する力 が, あらかじめわかれば, ダイヤフラムは単独に解析で きることになる. 文献 16) などでは, ダイヤフラムに作 用する力としてウェブからのせん断力のみを考慮して, ダイヤフラムを単体として解析している.ここでは，モ デル T 2, U 2 F, U 2 FR のダイヤフラムに対する不静

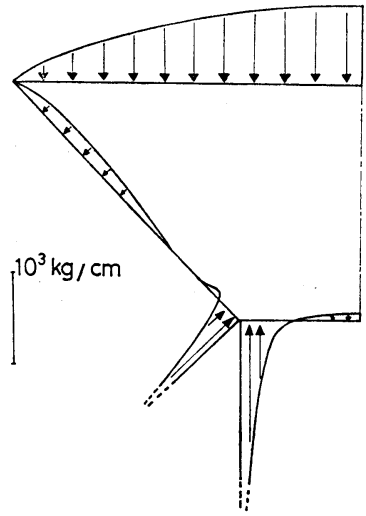

(a) 辺に垂直な力

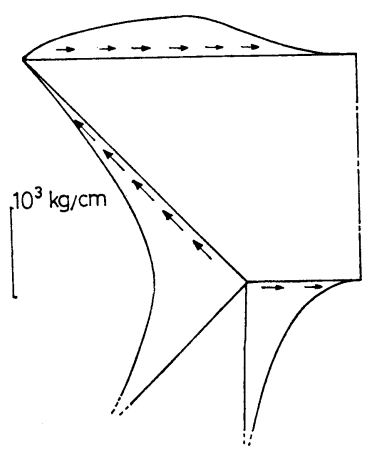

(b) ウェフ・フランジからのせん断力

図一17 ウェブ・フランジからの不静定力（モデル T2） 


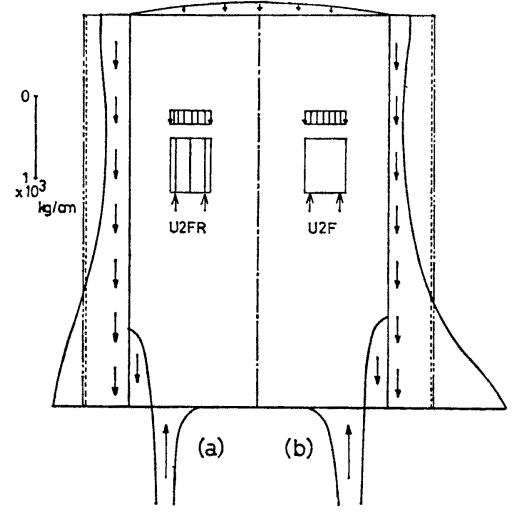

図一18 ウェブ・フランジからの不静定力 (タイプRの箱桁)

定力を示すとともに, 台形断面桁のダイヤフラムの応力 分布については, 文献 16) と比較してみる.

モデル T 2 の S.D. に対する不静定力は, 図一17 の ようになる．このモデルでは，上フランジに等分布荷重 を满載しているため, ダイヤフラム上辺に圧縮力が作用 している. 支点付近で大きな力がみられ，側辺に作用す る力も文献 16) と逆になっているのは，この図では支点 反力の影響む含んでいるからである。一方，タイプEの モデル U $2 \mathrm{~F}, \mathrm{U} 2 \mathrm{FR}$ について同様な図を描くと, 図 -18(a), (b) のようになる（図一18 では，鉛直方向の 力のみ示してある)。このモデルの場合には，ウェブか らの下向きのせん断力が, ダイヤフラム上辺の等分布荷 重による圧縮力上りはるかに大きくなっている.これ は，このモデルでは支点がウェブ直下ではなく, やや内 側に寄った場所にあるためと考えられる。

図一18(a), (b) において，破線はこのダイヤフラム 側辺に作用するせん断力の平均值を示しており，また， 二点鎖線は支点反力をダイヤフラム側辺の長さで割った 值である.これを見ると，モデル U 2 FR では，ダイヤ フラム側辺に作用するせん断力を, これらの直線で近似 しても，ダイヤフラムの応力は㧍㧍むね評価できると思 われる. 一方，ダイヤフラムにリブのないモデル U $2 \mathrm{~F}$ では, このせん断力は上部と下部の差が大きく,これら の直線での近似は若干の無理があろう。

次に， c) で得られたダイヤフラムの応力分布を, 文 献 16) の結果と比較する. 文献 16) では，ダイヤフラム のみを取り出し, 平面応力状態として扱っている. 本解 析に用いたモデルのうち, 台形断面桁（モデル T 2, T $2 \mathrm{~S}$ ，T 3）は, 寸法や板厚, 材料定数は文献 16) のモデ ルに合わせてある. 荷重は，文献 16）では，図一19に あるようにダイヤフラム側辺に線荷重のように作用させ ている。これは，荷重はウェブからのせん断力としてダ イヤフラムに作用する，としたものである。なお，文献

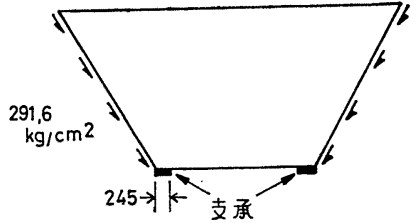

(a) モ
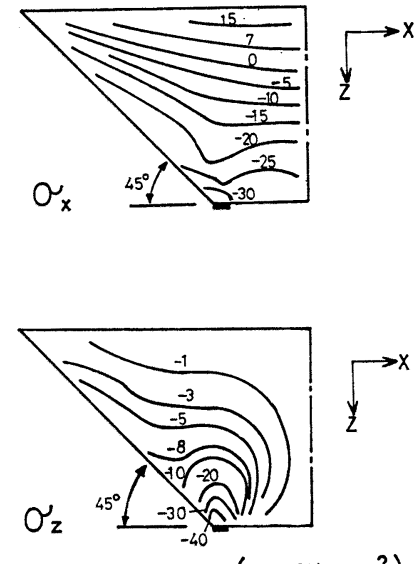

$\left(x 70.31 \mathrm{~kg} / \mathrm{cm}^{2}\right)$

(b) 結 果

図一19 文献 16) のモデルおよび結果

16）と本解析とでは，荷重の条件が異なるため，分布の 傾向についてのみ論ずる. 文献 16) の結果を 図一19に 示す.

モデル T 2S では, 荷重状態が文献 16）と似ている ため，ダイヤフラムの面内応力分布は，ほとんど同じ形 となった．水平方向応力 $\sigma_{x}$ 注支点の近くで，鉛直方向 応力 $\sigma_{z}$ はダイヤフラム上部で, 若干の相違が見られる 程度である。

等分布荷重を満載した箱桁（モデル T 2，T 3) では， 水平方向応力 $\sigma_{x}$ の分布は, 文献 16) とまったく異なっ ている. 鉛直方向応力 $\sigma_{z}$ についても，ダイヤフラム両 端を中心に異なる分布を示している。

g） 解析結果のまとめ

以上をまとめると，次のようになる.

箱桁のウェブ・フランジは，中間支承付近で大きな応 力がみられる。 また，フランジの応力は，端部と中央部 での応力の差も大きくなっている.

タイプ R の長方形断面では， I.D. には大きな応力 は発生しない. S.D. であっても，長方形断面では，大 きな水平方向応力 $\sigma_{x}$ は見られず, 鉛直方向の圧縮応力 が支配的である.また，I.D. の有無により，S.D. の応 力分布には大きな違いは見られなかった。

台形断面桁においても，I.D. の有無は，S.D. に大き な影響を与えてはいない，したがって，本論文のような 等分布荷重を満載したような場合には，中間ダイヤフラ 
ムは，支承部の応力に対しては効果は少ないといえよ う.ただし，ずり荷重のような荷重が作用する断面変形 問題では，中間ダイヤフラムが重要であることは，文献 2) などに示されている.

また，台形断面では，I.D.においても，鉛直方向応 力 $\sigma_{z}$ は部分的に大きな值がみられた.

ダイヤフラムにリブがつくことにより，ダイヤフラム の応力は当然小さくなるが, リブの剛度を変えた場合の 結果からは, リブの面積比 $\delta$ を $\delta_{s}$ の 3〜4 倍程度以上 としても意味のないことがわかる. ダイヤフラムの応力 そのものは, 特異点の近傍をのぞくと, リブの面積比 $\delta$ が $\delta_{s}$ の $1 / 2$ 程度ですでに小さくなっている.

支点がウェブ直下にある場合には，支点がやや内側に 寄り，ダイヤフラムを直接支えるものよりもダイヤフラ ムの応力は当然小さくなっている. この場合には, ダイ ヤフラムのリブの有無に関係なくウェブに大きな圧縮力 がみられ，ウェブに対する補剛材の必要性を示してい る.ただし，本論文におけるこのモデルでは，主として ダイヤフラムに注目しており，ウェブの補剛については 考慮していない.

文献 16) と本解析の結果を比較すると, 荷重条件の似 ているモデル T $2 \mathrm{~S}$ は, ダイヤフラムの応力分布の傾 向は，ほぼ一致した. したがって，図-3(b) の Case 3 のような荷重が作用する場合には, その荷重と等価なせ ん断力を, ダイヤフラムと同形の平面応力状態の板に作 用させることにより，ダイヤフラムの忍力を評価できる といえる.しかし, 現実の構造物においては, 図一3(b) の Case 3 のような荷重をうけることは, まれである.

本解析より得られた, 等分布荷重満載の場合の台形断 面桁のダイヤフラムの水平方向応力 $\sigma_{x}$ は, 文献 16) の 結果とは大きく異なっており, 鉛直方向応力 $\sigma_{z}$ につい ても，ダイヤフラム上半部を中心に異なる傾向をみせて いる.

ダイヤフラムのみを取り出して解析することは, 解析 が簡単になるなどの利点はあるが，この場合には，ダイ ヤフラムに作用する力は, ウェブからのせん断力のみで なく, 現実に近い状態で解析することの必要性も検討す べきであろう．たとえば，等分布荷重を満載した台形断 面桁・モデル T 2 の場合, ダイヤフラム上辺に大きな 圧縮力が作用しており, ウェブからのせん断力のみを考 慮しただけではダイヤフラムの応力は正しく評価できな いと思われる. 一方, 同じく等分布荷重を満載したモデ ル U $2 F R$ では, 図一22 で, 二点鎖線で示した等分布 せん断力をウェブに作用させることにより，ダイヤフラ ムの応力は扔拉むね評価できるといえよう。

この論文では, 解析はすべて弾性・微小変形の範囲内 で扱い, ダイヤフラムは平面応力状態にあるものとし
た. また, 収束性の点からも, 中間支承近傍の応力を把 握することはできなかった. さらに, タイプ $\mathrm{E} の$ 箱析で は, 数值解析のつごうで, ダイヤフラムの要素分割は支 点付近でも粗くせざるを得ず，この意味で不完全な解析 となったことは否めない. 応力集中点付近の応力を算定 するためには, 弾性範囲外までを考虑した取扱いや，要 素分割をさらに細かくするなどのくふらが必要となろ う. 中間支承上のダイヤフラムも, 大きな圧縮力をうけ るので, 面外変形や座屈までを考慮した解析がなされる べきであろう.

\section{6. まとめ}

FSM および FEM により, 特に, ダイヤフラムの応 力状態などに注目して, 連続箱桁を解析した. そして, ダイヤフラムの応力分布や, 従来の研究ではあまり触れ られていない, ダイヤフラムに作用する不静定力などを 示した.

本論文では，モデルとしてごく簡単な一室箱桁を用 い, 荷重も等分布荷重満載, あるいは中間支点からの反 力のみを考慮するなどの単純な場合のみを扱った．この ような限られた範囲内の計算ではあるが, 他の場合で も, ある程度はこれらの結果が間中支承部における箱桁 等の応力状態を予測するための資料とすることができる ものと思われる.

今後は，これ以外の種々の条件のもとでの解析をする とともに, 実験などとの比較も必要となろう.さらに, 解析においても, 弾性範囲外, あるいは座屈までを考慮 した議論をすべきであろう.

本解析には, 名古屋大学, および東京大学の大型計算 機センターを利用したことを付記しておく.

\section{参考文 献}

1) The Committee of Inquiry into Basis of Design and Method of Erection of Steel Box Girder Bridges: Interium Design and Workmanship Rules, Her Majesty Stationaly Office, London (1973) (Merrison レ ポート・橋梁と基礎 73-3〜 74-5 などに，成岡ほかによる 邦訳がある).

2）奥村敏恵・坂井藤一：箱型ばりの断面変形と中間ダイア フラムの影響, 土木学会論文報告集, 190 号, pp. 23 36, 1971.6.

3) 奥村敏恵・坂井藤一：リブ付台形析の断面変形挙動とダ イアフラムの効果, 土木学会論文報告集, 209 号, pp. 1 $\sim 14,1973.11$.

4）坂井藤一・長井正䐀 : 鋼箱げた橋におけるダイアフラム 關澵の決定に関する一試案, 関西道路協会々報, 2 , pp. $37 \sim 42,1976.11$.

5）奥村敏恵・坂井藤一：薄肉平板より成る立体的構造物の 静力学的解析に関する一方法とその忘用, 土木学会論文 報告集, 176 号, pp. 43〜 59, 1970.4.

6）大塚久哲・吉村虎藏・彦坂 熙・藤津卓司: 有限帯板法 による中間隔壁をもつ曲線箱桁橋の解析, 九大工学集報, 
49.2, pp. $67 \sim 74,1976.2$.

7) Abdel-Samad, S.R. : Analysis of Multicell Box Girders with Diaphragms, Ph.D. Thesis, Univ. Illinois, 1967.

8) Abdel-Samad, S.R., Write, R.N., and Robinson, A. R. : Analysis of Box Girders with Diaphragms, Proc. ASCE, 94, ST 10, pp. 2231 2256, 1968.

9) Write, R.N., Abdel-Samad, S.R., and Robinson, A. R. : BEF Analogy for Analysis of Box Girders, Proc. ASCE, 94, ST 7, pp. 1719 1743, 1968.

10) Djubek, J., and Balaz, I. : Box Shaped Girders, Int. Jour. Mech. Sci., 17, pp. 617 626, 1975.

11) Chapman, J.C., Dowling, P.J., Lim, P.T.K., and Billington, C.J. : The Structural Behaviour of Steel and Concrete Box Girder Bridges, Structural Engeneer, 49, pp. 111 120, 1971.

12) Champbell-Allen, D., and Wedgewood, R.J.L. : Need for Diaphragm in Concrete Box Girders, Proc. ASCE, 97, ST 3, pp. 825 842, 1971.

13) Sisodia, R.G., Ghali, A., and Cheung, Y.K. : Diaphragms in Single and Double-Cell Box Bridge with Varing Angle of Skew, J. ACI, pp. 415 419, 1972.

14) Rabizadeh, R.O., and Shore, S. : Dynamic Analysis of Curved Box-Girder Bridges, Proc. ASCE, 101, ST 9, pp. 1899 1912, 1975.

15) Lees, A.W., Thomas, D.L., and Wilson, R.R. : Analysis of Vibration of Box Beams, Jour. Sound Vib., 45, pp. 559 568, 1976.

16) Rockey, K.C., and El-Gaaly, M.A. : Stability of Load Bearing Trapezoidal Diaphragms, Publ. IABSE, 32II, pp. 155 172, 1972.

17) El-Gaaly, M.A. : Stability of Orthogonally Stiffened Load Bearing Trapezoidal Diaphragms, Publ. IABSE, 34-II, pp. 73 89, 1974.

18) Dowling, P.J. and Loe, J.A. : The Behaviour up to Collapse of Load Bearing Diaphragms in Rectangular and Torapezoid Stiffened Steel Box Girders, Steel Box Girder Bridges, pp. 95 117, proceedings of the
International Conference Organized by ICE, London, 13-14, Feb.,1973.

19）中村秀治：断面変形を考虑した薄肉ばりの振動解析，土 木学会論文報告集, 223 号, pp. 11〜22, 1974.3.

20）坂井藤一・中村秀治：薄肉曲線ばりの板㪍構造としての 一解析法, 土木学会論文報告集, 235 号, pp. 41 54, 1975. 3.

21）清水 茂・吉田俊弥・梶田建夫：ダイヤフラムを有する 箱桁の挙動について, 土木学会中部支部研究発表会概要 集, pp. 11 12, 1977.

22) Cheung, Y.K. : Folded Plate Structures by Finite Strip Method, Proc. ASCE, 95, ST 12, pp. 2963 $2979,1969$.

23）坂井藤一・長井正品司, 佐野信一郎 : ブロック有限要素法 による薄肉箱げたの立体解析, 土木学会論文報告集, 255 号, pp. 17〜29, 1976.11.

24）仮井藤一・長井正嗣 : 鋼箱桁橋の中間ダイアフラム設計 法に関する一試案, 土木学会論文報告集, 261 号, pp. 21 〜34, 1977.5.

25）大塚久哲・吉村虎蔵・彦坂 熙・平田勝啓 : 床版と桁の 偏心結合を考慮した曲線桁橋の解析, 土木学会論文報告 集, 259 号, pp. 11 23, 1977.3.

26) Priestley, M.J.N. : Testing a Single Cell Box-Girder Model, Road Research Unit Bulletin, No. 25, National Road Boad, New Zealand 1974.

27) Hirashima, M., Yajima, S. : Beitrag zur Brechnungen von Querschotten in Hohlkastenträgen, Proc. JSCE, No. 264, pp. 113 123, 1977. 8.

28）大塚久哲・吉村虎蔵・彦坂 熙：曲線箱栴に㧍ける中間 隔壁の補剛効果, 橋梁と基礎，78-1， pp. 39～42, 78-2, pp. $40 \sim 43,1978$.

29) Puthli, R.S., Crisfield, M.A. : The Strength of Stiffened Box Girder Diaphragms, T.R.R.L. Supplementary Report 353, Structural Department, Transport and Road Research Laboratory, Crowthorne, Berkshire, 1977.

(1977.7.20 - 受付) 